\title{
Study of Mobile Phone Gratification Sought and Obtained by Aquaculture Farmers as Strategy for Advisory Services in Nigeria
}

\author{
Ifejika, P.I ${ }^{1}$, I.O. Oladosu' ${ }^{2}$, L.I. Ifejika ${ }^{3}$, A.N. Asadu ${ }^{4}$, P.T. Laniran ${ }^{5}$ \\ ${ }^{1}$ National Institute for Freshwater Fisheries Research, P.M.B. 6006, New-Bussa, Niger State, Nigeria \\ E-mails: Ifejikaphilip@gmail.com\&ifejikaphilip@yahoo.com \\ WhatsApp: +2347089523717 \\ ${ }^{2}$ Department of Agricultural Extension and Rural Development,Ladoke Akintola University of Technology, Ogbomosho, \\ Oyo State, Nigeria \\ ${ }^{3}$ Department of Home and Rural Economics,Federal College of Freshwater Fisheries Technology, New-Bussa, Niger State. \\ ${ }^{4}$ Department of Agricultural Extension, University of Nigeria Nsukka, Enugu State, Nigeria \\ ${ }^{5}$ West and Central African Council for Agricultural Research and Development (CORAF/WECARD), Dakar, Senegal
}

\begin{abstract}
Mobile phone is strategic in the current effort to improve advisory services delivery and effectiveness of information sharing toenhance aquaculture entrepreneurship for food security, and wealth creation in the country. This prompted the study of mobile phone gratification sought and obtained among table size aquaculture fish food producers through the application of Uses and Gratification Theory. In pursuit of the set objectives, primary data was generated from 100 respondents in Niger State, Nigeria which was analysed with descriptive and inferential statistic tools. Personal profile revealed dominance of aquapreneur by people in middle age categories with mean age of 42 years and 4.5year of experience. Respondents top gratifications sought from mobile phone usage were to be accessible, connected, job accomplishment and socialization whereas obtained gratifications in enterprise were to support adoption of technologies, timely information, linkage to customers, quick response, and access to inputs. It was revealed that respondents had positive antecedent to mobile phone services subscription relating to caller tone, music, news alert, sports, and health. Socio-economic variables that correlate with gratification sought and obtained were marital status, religion, and education at 0.05 level. In view of the finding on responsible usage of mobile phone in aquaculture enterprise, more investment is required develop mobile phone applications and services. To sustain and improve on the benefits derived, respondents need capacity building to acquire more knowledge and skills to effectively participate in advisory services.
\end{abstract}

Keywords-Mobile phone, aquaculture, gratification, innovative platform, Nigeria.

\section{INTRODUCTION}

Mobile phone technology is driving contemporary information society and behaviour which is transforming economies and livelihood activities at global, regional, national and individual levels. Report of GSM Association (2015a) revealed that as at 2014, global mobile industry achieved 3.6 billion subscribers, 50\% penetration, 7.3 billion SIM connections, 2.4 billion mobile internet users, 2.6 billion smartphones adopters, $39 \%$ of $3 / 4 \mathrm{G}$ connections and contributed $\$ 3.0$ trillion to gross domestic product (GDP). In sub-Saharan Africa, it is good news with 367 million subscribers representing $41 \%$ penetration rate, 680 million SIM connections representing $77 \%$ penetration rate, $24 \%$ broadband connection, 160million smartphone users and contributed $\$ 100$ billion to the region's economy in 2015 (GSMA, 2015b). In the case of Nigeria as at June, 2016, there exist 213,113,202million connected GSM lines of which the active lines were $149,179,083(70 \%)$ whereas internet users stood at 86million (http://www.ncc.gov.ng/).

Above evidence points to positive impact of mobile phone technologies in diverse business situations in many countries. Ogbeide and Ele, (2015) posits that it provides different opportunities to transfer information and knowledge among stakeholders in the agribusiness value chain. Therefore, deployment of mobile technologies which exist in infrastructure, services, and applications is capable of accelerating access to quality and effective information to agricultural community in the region. An innovation mix of mobile phone with radio programs (call-in or SMS) facilitates interaction, feedback and most cost-effective solution.

The World Bank (2006) acknowledged that information is a factor of production as enterprise do better with 
information and communication. By implication, information is an input required by actors in agricultural value chain to take informed decision. As such, evolution of mobile phone has increased farmers' investment in information as an input through ownership, subscription and access to applications and services. Aker (2010) highlighted mobile phone functions and benefits in agricultural extension services whereas Gakuru et al. (2009) shared evidences of mobile phone in advisory services in sixteen African countries. On productivity, Bayes (2001) established higher returns of using mobile services for the poor compared to the non-poor. Mobile phones have been found to help improve the productivity of individuals and organizations within resourceconstrained environments due to increased efficiency, effectiveness, and reach (Qiang, et al., 2011; Hudson, 2006). In Nigeria, Ogbeide and Ele (2015) established that crop and livestock farmers that use mobile phone to access market and financial information significantly increased productivity .In capture and aquaculture fishery, Aphunu and Atoma (2011), Ifejika (2013) and Jiriko et. al (2015) established mobile phone ownership and usage to access fisheries information. Also, Ifejika (2015) empirically found that mobile phone ownership facilitates storage and evaluation of aquaculture information before usage.

In aquaculture production, mobile phone applications are needed for fish species identification, fingerlings counting, fish sex detection, water quality parameters measurement in pond, fish disease and adulterated fish feed. Likewise, mobile phone advisory services are needed to overcome extension deficiencies in manpower, knowledge, cover distance and effectiveness. Hecht (2006) hinted that aquaculture in sub-saharan Africa is contributing less than $1 \%$ to world aquaculture production. In 2015, fish production in Africa amounted to 11 million tons with $85 \%$ coming from catch fishing and $15 \%$ from fish farming which accounted for $7 \%$ of the world production (Ntagungira, 2016). However, outrageous fish importation bill of US\$2.006billion spent by west African countries is a big threat to aquaculture development in the sub region.

In Nigeria, aquaculture performance is encouraging and exemplary in the sub region. It is interesting to note that Nigeria's aquaculture growth which picked up in 2000 coincided with the introduction of mobile phone in the same year. According to Federal Ministry of Agriculture and Rural Development (FMARD) (2012),aquaculture has attained double digit growth of $20 \%$ in domestic fish production from $5.50 \%$ to $24.75 \%$ between 2003 and 2011. Other positive attributes of aquaculture are; highly profitable venture of which the cost of production was $\$ 571,231.79$, the total revenue of $\$ 5,853,625.64$ and the net income was $\$ 5,282,393.85$ as found in Kaduna State (Kudi etal 2008); generates monthly income of $\$ 26$, 553.40 which is higher than national minimum wage of $\$ 19$, 000= US\$126.67 (Oluwemimo and Damilola, 2013); fish farming activity reduces poverty by $34.2 \%$ as found in Adamawa State (Ndamu 2016); catfish fingerling producers attest that patronage was encouraging and demand for fingerlings is more than supply in Borno State (Olanrewaju et al, 2010); attractive to economic active age group including women and youths (Ifejika et al, 2015; Ndamu, 2016; Kudi et al, 2008). Others are transformation of a rural community is the case of "MonaiFish Farming Village" in Borgu council, Niger State, wealth creation in the value chain for hatchery operators, table size growers, fish feed millers and producers, input dealers, pond construction, fish smoking, security guards and attendants, hiring of ponds, transporters, fish marketing, and increase value of land.

Muir (2005) predicted that aquaculture should develop rapidly to increase by over $260 \%$ which translates to an annual average of more than $8.3 \%$ by 2020 . Aquaculture in the region with less than $5 \%$ of the suitable land area being used, deserve attention and investment in mobile phone technologies services and applications for information delivery. Meanwhile, huge gap exists in literature on studies of mobile phone dedicated to aquaculture as well as on the application of Uses and Gratification Theory (UGT). Communication experts provided a new dimension in the study of mobile phone through UGT which provides insight on "why and how". Ruggiero (2000) wrote that as new mobile technologies present people with more and more media choices, motivation and satisfaction become even more crucial components of audience analysis. UGT belongs to social functionalism and psychological communication perspective school of thought (Luo, 2002). UGT is useful in understanding of gratifications sought and obtained as well as helpful in clarifying activity and activeness of media audiences. "Activity" refers to what the media consumer does whereas "activeness" refers to the audience's freedom and autonomy. In this direction, Quan-Haase and Young (2010) and Ruggiero (2000) posits that new media like mobile phone possess at least three attributes not commonly associated with traditional media: interactivity, demassification, and asynchroneity. Above attributes are critical in emerging mobile phone platforms in extension advisory services. Present study seeks to break the jinx and unfold why fish farmers acquire mobile phone and benefits derived from its usage in fish farming activity. Above arguments informed the decision to carry out investigation on aquaculture farmers' gratification sought and obtained from mobile 
phone and its consequences on advisory services as strategy for aqua-business in the region.

Therefore, the study seeks to provide answers to the following research questions:

1. What are the gratifications fish farmers' sought and obtained from mobile phone?

2. What is their mobile phone communication behaviour?

3. What are their antecedents' to mobile phone services subscription?

4. What is their personal profile?

II. HYPOTHESES TESTING FOR THE STUDY

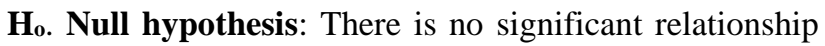
between gratifications sought and obtained from mobile with selected personal profiles of subjects.

H1. Alternative hypothesis: Significant relationship exists between gratifications sought and obtained from mobile with selected personal profiles in the States.

\section{AREA OF STUDY}

In Nigeria, Niger State is located in the north central geopolitical zone and in guinea savannah belt which lies on latitude $80^{\circ}$ to $11^{\circ}: 30^{\prime}$ North and Longitude $03^{\circ} 30^{\prime}$ to $07^{\circ}$ 40’ East (Niger State Planning Commission, 2011). It has twenty-five administrative councils and population figure of 3,950,249 million in 2006 census. About $85 \%$ of the land mass is arable whereas three hydroelectric power dams boostcapture fishing livelihoods. Based on survey of fish farms in the country, Niger State was categorized as low aquaculture zone due to low number of operators (AIFP Project, 2004). Between then and now, evidences of aquaculture intensification and scaling up are visible in Minna, Bida and New-Bussa environs. In the State, aquaculture is attracting investment, growth in number and practices which is quite significant and contributing to job creation, income and food security in the value chain.

\section{METHODOLOGY}

Secondary information collected from Fisheries Subject Matter Specialist in the State Agricultural Development Programme (ADP), Research Institution, Fish Farmers groups in Minna, New Bussa and Bida as well as physical observations put the number of fish farmers in the State at close to 1080 which is the population for the study. While the study sample sizewas contact fish farmers with ADP and NIFFR found to be 250 . Respondents' were randomly selected 110 active contact fish farmers' in the last six months representing $44 \%$ of the sample size. After data collection, ten respondents were discarded due to error from enumerators hence the valid respondents were 100 . Primary data was generated from respondents in the three ADP zones namely Minna, Bida and Kontagora in the month of April to July, 2013. Instrument for data collection was semi-structured questionnaire which was face validated by experts in agricultural extension and fisheries subject matter specialist. Reliability was measured with Cronbach Alpha values and alpha value of 0.70 coefficients was obtained which confirmed instrument as reliable. Primary data was collected through face to face interview by trained enumerators fluent in local and English languages. Variables were measured at nominal, ordinal and interval levels and scored accordingly. Dasgupta (1989) procedure was adopted to categorise respondents into high $(50 \%<)$ and low $(50 \%$ $>$ ) from the index score. Generated data was analysed with descriptive and inferential tools of frequency, mean, percentage, standard deviation and Pearson Product Moment of Correlation (PPMC) which is presented in tables, figures and charts.

\section{RESULT AND DISCUSSIONS}

Figure 1 show respondents' antecedent behaviour to adoption of subscribed mobile phone services which discloses familiarity with mobile phone services. Mean adoption score revealed low antecedent behaviour by majority $(57 \%)$ to mobile phone services compared to highantecedent behaviour (43\%). Respondents' antecedents suggest high awareness but low adoption of services. Subscribed mobile phone services among respondents with high adoption above the mean score (> 27 ) were on caller tone $(32 \%)$, news alert $(20 \%)$, music $(19 \%)$ while low adoption behaviour below the mean score $(<27)$ was observed in joke, health, love, and sport services. Probably, low adoption of subscribed services among fish farmers can be traced to high charges ranging from $\$ 50$ to $¥ 100$, reckless deduction of credit by service providers, unappealing andirrelevant messages. These factors might be responsible for the negative reaction of respondents to stop usage by $0.71 \%$ and trial only without adoption by $12.28 \%$. Respondents antecedents predict possibility of participation in mediated aquaculture mobile phone advisory services. However, discontinuance behaviour is a caution that respondents will pull out if subscribed services don't meet expectations to satisfy information need in terms of quality, efficiency and effectiveness. 
Source: Field data (2013)

Displayed in Table 1 is result of gratifications sought by aquaculture farmers to acquire mobile phone. Total mean score confirmed that higher proportion of subjects $(57 \%)$ sought high gratification against smaller proportion (43\%) to acquire mobile phones. Sought gratifications with high expectations $(>=39.9$ ) among subjects was found to be mobile and accessible (96\%), connect to people (81\%), job accomplishment (68\%) and socialization (45\%) whereas low motive was observed on time management $(32 \%)$, security and boost image $(30 \%)$ respectively. The result confirmed that aquaculture farmers were highly motivated to acquire mobile phone to satisfy social and job related task among others. Wei (2001), Wei and Lo (2006) studies corroborated the finding on high gratification sought for usage of mobile phone on mobility, intimacy, job and sociability. Response on job gratification by $68 \%$ justify investment in mobile phone acquisition and subscription to services as an input with return on investment.

Table.1: Respondents gratification sought to acquire mobile phone (\%)

Sought variables
Socialization
Job Accomplishment
Connected to people
Time management
Mobile \& Accessible
Security
Boost image

$\begin{array}{ccc}\text { No } & \text { Low } & \text { High } \\ 12 & 43 & 45 \\ 6 & 26 & 68 \\ 4 & 15 & 81 \\ 46 & 22 & 32 \\ 2 & 2 & 96 \\ 40 & 30 & 30 \\ 31 & 39 & 30\end{array}$

\section{Categorization}

Mean

\section{Standard deviation}

39.9 (> = high), $0.365(<=$ low $)$

High

\section{2}

57

Low

Source: Field data (2013)

Table 2 provides information on job gratifications obtained from using mobile phone in aquaculture practice. Mean score $(78.2 \%)$ attests that majority $(71 \%)$ obtained high benefits on aquaculture work compared few $(29 \%)$ that derived low benefit. As seen, mobile phone facilitated the following benefits: adoption of 
technologies (99\%), timely information delivery \& link to customers (94\%) respectively, market information (92\%), quick response/intervention (90\%) among others satisfactions in the table below. The findings on high job gratificationsobtained in the usage mobile phone in economic activity agreed with Puro (2002) and Hooper and Zhou(2007). Positive contribution of mobile phone to accomplishment of work task justify investment in subscription to servicesand applications. It further attests to mobile phone delivery of quality information in terms of relevance, credibility and effectiveness to support decision making process among aquaculture farmers.

Table.2: Job related gratifications obtained in aquaculture practice

$\begin{array}{lcc}\text { Benefits obtained } & \text { No } & \text { Yes } \\ \text { Timely information } & 6 & 94 \\ \text { Take informed decision } & 21 & 79 \\ \text { Adopt new technologies } & 1 & 99 \\ \text { Increase fish yield } & 16 & 84 \\ \text { Link customers } & 16 & 94 \\ \text { Market information } & 8 & 92 \\ \text { Better sells \& profit } & 16 & 84 \\ \text { Improve access to inputs } & 19 & 81 \\ \text { Quick response \& intervention } & 10 & 90 \\ \text { Reduce risk } & 17 & 83 \\ \text { Categorization } & & \\ \text { Mean } & & 78.2 \\ \text { Low } & & 29 \\ \text { High } & & 71\end{array}$

Source: Field data (2013)

As shown in Table 4, respondents mean age (42yeras) was slightly above the young group category indicating dominance of people in the early and middle adulthood $(52 \%)$ than the youth and young categories $(44 \%)$ in fish farming. Ifejika et al (2015) and Karem et al (2009) agreed on the activeness of the two age categories as contending force in aquaculture. On gender, men $(82 \%)$ dominated aquaculture practice over the women (18\%) in the study area. Previous findings consistent with the result on men dominating aquaculture enterprise were Ifejika $e t$ al (2015) and Karem et al (2009). However, women involvement in fish farming enterprise is gradually rising unlike ten years ago in the country. Probably, investment in mobile phone services and applications in aquaculture might provide the needed leverage to attract more women. Result on religion indicates that it is not a barrier to the practice of catfish fish farming in the States by either Muslim (59\%) or Christians (41\%). Rather religious should be an asset for platform formation as network to promote knowledge sharing and solve challenges in aquaculture. On marital status, majority were married $(75 \%)$ and few singles $(21 \%)$ among the young people. Corroborating the fact on high involvement of family members over singles in aquaculture enterprises in the country were Ifejika et al (2007), Nwosu and Onyeneke, (2013). Fish farming is supporting family farming enterprises which provides income, food and job security as well as labour, information and entry point. Majority (50\%) had between 4-6years, 34\% had between 1-3years which signify that $95 \%$ entered the business in less than ten years.Experience is a critical factor to success of aquaculture practice as most operators depend on past knowledge to evaluate information before usage. In view of this result, fish farmers' opinions should be respected and consulted in aquaculture mobile phone advisory services. Response on education strongly confirmed that fish farming is an elite agricultural enterprise compared to crop and livestock. Large proportions of respondents $(81 \%)$ hold higher degrees of National Diploma (33\%), BSc $(35 \%)$ and MSc (16\%). In agreement with the result on engagement of graduates into fish family were Karem et al (2009) who found $82 \%$ as graduates in Ogun State and Okunola et al (2011) found 63\% in Ondo State. This development is a good omen for aquaculture as they will be flexible in thinking and innovative towards mobile phone driven advisory services. Response on English language communication skill, over $90 \%$ affirmed to have competency to read, write and speak English language very well. This is not surprising as over $80 \%$ of them were graduates, hence, dissemination of aquaculture information in English language will not be a challenge to subscribers. As such respondents, can make use of verbal and nonverbal communication tools to send and receive information with mobile phone. 
Table.4: Personal profile of respondents

\section{Age}

20-30 Youth

31-40 (Young)

41-50 (Early adulthood)

51-60 (Middle adulthood)

$<61$ (Late adulthood0

Mean

Religion

Christianity

Muslim

Traditional

Marital status

Single

Married

Widow

Divorced

\section{Language skill}

Speak Good English

Read Good English

Write Good English

\section{$\%$}

23

21

28

24

4

42

41

59

0

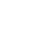

21

75

4

0

No

2

2

2

\section{Years of experience}

1 to 3

4 to 6

7 to 9

10 to 12

13 to 15

Mean

Education

No school

4.52

Primary

JSS

SSS

NCE/ND

$\mathrm{BSc}$

MSc

Gender

Men

Women

Partial
7
7
6

$\%$

34

50

11

3

2

2

0

0

14

33

35

16

82

18

Very well

91

91

92

Source: Field data (2013)

Table 5 shows result of personal variables that correlates with gratification sought and obtained. Personal characteristicsthat positively correlated with mobile phone gratification sought were religion $(\mathrm{p}=.029)$ and marital status $(p=.000)$ whereas gratification obtained were positively correlated with education $(\mathrm{p}=.017)$.Collaborating the finding was Ofuoku et al., (2007) on the positive contribution of education to usage of mobile phone among poultry farmers in Delta State. By implication, education influences thinking and reasoning of farmers towards adoption of innovation. This is an indication that respondents need capacity building to build knowledge and skills to derive more benefits from mobile phone usage. Also, training will stimulate positive attitude and behaviour necessary for participation and investment in mobile phone services initiative in aquaculture value chain.

\begin{tabular}{|l|l|l|l|}
\hline \multicolumn{4}{|c|}{ Table.5: Correlation analysis between gratification sought and obtained with selected personal } \\
characteristics \\
\hline Independent Variables & Correlation coefficient (r) & p-value $\left(\mathbf{r}^{2}\right)$ & Remarks \\
\hline Age & $-.151^{\text {sought }}$ & .133 & Negative \&weak NS \\
& $.083^{\text {obtain }}$ & .412 & Positive \&weak NS \\
\hline Gender & $-.152^{\text {sought }}$ & .132 & Negative \&weak NS \\
& $-.059^{\text {obtain }}$ & .562 & Negative \&weak NS \\
\hline Marital status & $-.218^{\text {Sought }}$ & .029 & Negative \& positive s* \\
& $-.015^{\text {obtain }}$ & .88 & Negative \& weak NS \\
\hline Religion & $-.417^{\text {sought }}$ & .000 & Negative \& stable* \\
& $-.023^{\text {obtain }}$ & .821 & Negative \& weak NS \\
\hline Education & $.239^{\text {obtained }}$ & .017 & Positive \& strong S* \\
\hline
\end{tabular}

Significant; $*=0.05$ levels; $* *=0.001$ levels 


\section{CONCLUSION AND RECOMMENDATIONS}

Outcome of the study was useful in understanding the gratifications fish farmers sought and obtained byacquiring mobile phone and their antecedent behaviour to mobile services.Respondents are deriving high gratification from mobile phone to support their aquaculture enterprise. Education and accomplishment of family responsibilities are influencing the responsible usage of mobile phone in fish farming activities. As such, aquaculture operators the study area are ready to invest and subscribe to mobile phone services platform that will deliver useful information. Government and private services providers are encouraged to consider setting up mobile phone platform for aquaculture farmers. Also, investment is highly needed in mobile phone applications that will help reduce drudgery, support adoption and market information access.

\section{REFERENCES}

[1] Aker, J.C (2010). Dial "A" for agriculture: Using information and communication technologies for agricultural extension in developing countries. AfDR_Aker_Dial-A-for-Agriculture P-S pdf file. pp $1-\overline{4}$

[2] AIFP Project(2004) Inventory of Fish Farms in Nigeria, Aquaculture and Inland Fisheries Project, National Special Programme for Food Security, Project Technical Document.

[3] Aphunu, A. and Atoma, C. N. (2011). Extent of Use of ICTs by Fish Farmers in Isoko Agricultural Zone of Delta State, Nigeria. Journal of Agricultural Extension, 15 (1). http://www.dx.doi.org/10.4314/jae.v15i1.2

[4] Bayes, A. (2001): Infrastructure and rural development: insights from a Grameen Bank Village Phone Initiative in Bangladesh. Agricultural Economics, 25(2-3), 261-272.

[5] Dasgupta, I. (1989). Diffusion of agricultural innovation in village India. Wiley Eastern Ltd.,New Delhi.

[6] Federal Ministry of Agriculture and Rural Development, (FMARD) (2012). Nigerian Fish Production by Sector between 1995 to 2011

[7] Gakuru, M., Winters, K., Stepman, F. (2009). Innovative Farmer Advisory Services Using ICT. "Africa Perspective on the Role of Mobile Technologies in Fostering Social Development" W3C Workshop.

[8] GSMA (2015b).The Mobile Economy. Sub-Saharan Africa 2015. Accessed on 7/2/2017 from http://www.gsma.com/mobileeconomy/archive/GS MA_ME_SubSaharanAfrica_2015.pdf

[9] GSMA Global Mobile Economy Report (2015a). Accessed on $7 / 2 / 2017$ from http://www.gsma.com/mobileeconomy/

[10] Hecht, T. (2006) Regional review on aquaculture development. 4. Sub-Saharan Africa -2005 .
FAO Fisheries Circular. No. 1017/4. Rome, FAO. 2006: 96.

[11]Hooper, V and Zhou, Y (2007). Addictive, dependent, compulsive? A study of mobile phone usage 20th Bled e-Conference eMergence: Merging and Emerging Technologies, Processes, and Institutions. June 4 - 6, 2007; Bled, Slovenia. Pp 272-285.

[12] Hudson, H. (2006). From rural village to global village: Telecommunications for development in the information age. Lawrence Erlbaum Associate, Danbury.

[13] Ifejika, P. I. (2013). Insight on How Fisherfolk Use Mobile Phone to Communicate in Fishing Communities of Kainji Lake Basin, Nigeria. International Journal of Information and Communication Technology Research, Vol. 3 No. 12, Nov-Dec, 316-322

[14] Ifejika, P.I. (2015). Assessment of fish farmers' information behaviour towards mobile phone innovative platform services in selected states of Nigeria. PhD Thesis, Department of Agricultural Extension, and Rural development, LAUTCH, Ogbomosho, Oyo State, Nigeria.

[15] Ifejika, P.I., Asadu, A.N., Enwelu, I.A., Sanni, A.O. Nwabeze, G.O. \&J. Omeje (2015). Determining Youth Choice of Enterprise iIn Aquaculture Production for Job Creation in Abia State, Nigeria. Nigerian Journal of Fisheries Vol. 12 (1): 808- 814.

[16] Ifejika, P.I., Ayanda, J.O., Sule, A.M. (2007). Socioeconomic Variables Affecting Aquaculture Production Practices in Borgu Local Government Area of Niger State, Nigeria. Journal of Agricultural Research, Vol.7, No.2. Pp 20-29.

[17] Jiriko, R. K., J. C. Obianuko and K. G. Jiriko (2015). Socio-economic factors affecting ICT utilization by youths in fish farming in kaduna state, Nigeria. Global Journal of Agricultural Research, Vol.3: 4. 12-22.

[18] Kareem, R.O., Aromolaran, A.B., and Dipeolu, A.O. (2009). Economic Efficiency of Fish Farming in Ogun State, Nigeria. Aquaculture Economics and Management, 13: 39-52

[19] Kudi TM, Bako FP, Atala TK (2008). Economics of Fish Production in Kaduna State, Nigeria. ARPN J. Agric. Biol. Sci., 3: 17- 21.

[20]Luo, X (2002). Uses and Gratifications Theory and E-Consumer Behaviours: A Structural EquationModelling Study. Journal of Interactive Advertising, Vol. 2 No. 2, Pp. 34-41.

[21] Muir, J. (2005). Managing to harvest? Perspectives on the potential of aquaculture. Philosophical Transactions Royal Society London B. Biological Science, $360 \quad$ (1453):191-218

[22] Ndamu, R. K. (2016) Fish Farming Enterprises and Poverty Reduction in Adamawa StateNigeria.Journal of Resources Development and Management, 12: 53-59 
[23] Niger State Planning Commission (2011). Statistical Year Book: Facts and Figures on Niger State.

[24] Ntagungira, C (2016). How to reverse the African propensity to import fish? Access from AFDB website on 7/2/2017. https://www.afdb.org/en/blogs/measuring-the-pulseof-economic-transformation-in-westafrica/post/comment-inverser-la-propensionafricaine-dimportation-de-poisson-16261

[25] Nwosu, C.S. and Onyeneke, R.U. (2013). Effect of Productive Inputs of Pond Fish Production on the Output of Fish in Owerri Agricultural Zone of Imo State, Nigeria. Global Advanced Research Journal of Agricultural Science, Vol. 2(1)023-028. Available online http://garj.org/garjas/index.htm

[26] Ofuoku, A.U.A., Isife, B.I., and Emah, G.N. (2007). Adoption of Mobile phone among Poultry Farmers in Delta State, Nigeria. Journal of Engineering and Applied Sciences 2 (1): 10- 16.

[27] Ogbeide, O.A and Ele, I (2015). Smallholder Farmers and Mobile Phone Technology in SubSahara Agriculture. Mayfair Journal of Information and Technology Management in Agriculture 1(1), 1-19.

[28] Okunlola, J.O., Oludare, A.O. and Akinwalere, B.O. (2011). Adoption of new technologies by fish farmers in Akure, Ondo state, Nigeria. Journal of Agricultural Technology 2011 Vol. 7(6): 15391548.

[29] Olanrewaju A.N., O.O. Agbelege, 1.F. Daddy and F.C. Okoye (2010). Fish Hatchery Survey in Borno State, Nigeria. Presentation at the 25th FISON Annual International Conference. Administrative Staff College of Nigeria (ASCON), Topo, Badagry, Lagos, Nigeria, 25th - 29th October, 2010: 88-93.

[30] Oluwemimo, O. and Damilola, A. (2013). Socioeconomic and policy issues determining sustainable fish farming in Nigeria. Journal of Agricultural Economics and Rural Development, Vol. 1(1): 035-041

[31] Puro, J (2002). Finland: A mobile culture in I.Katz and A, Aakhus (eds.), Perpetual Contact, Cambridge University Press, Cambridge. 19-29.

[32] Qiang, C.Z., Kuek, S. C., Dymond, A. \& Esselaar, S. (2011). Mobile Applications for Agriculture and Rural Development. Retrieved from http://siteresources.worldbank.org/INFORMATION ANDCOMMUNICATIONANDTECHNOLOGIES/ Resources/MobileApplications for_ARD.pdf

[33] Quan-Haase and Young, (2010). Uses and Gratifications of Social Media: A Comparison of Facebook and Instant Messaging. Bulletin of Science, Technology \& Society, 30(5) 350-361.

[34] Ruggiero, T.E. (2000). Uses and Gratifications Theory in the 21 st Century. Mass Communication \& Society, 3(1), 3-37

[35] Subscriber Statistics. Accessed in August, 2016 from http://www.ncc.gov.ng/
[36] Wei, R (2001). "From luxury to utility: A longitudinal analysis of cell phone laggards", $J \& M C$ Quarterly, vol. 78, pp. 702-719.

[37] Wei, R and Lo, V (2006). Staying connected while on the move: Cell phone use and social connectedness. New media and society, 8 (1) 53-72.

[38] World Bank. (2006). Overview of information and communications for development 2006: Global Trends and Policies. P3. Washington, D.C.http://siteresources.worldbank.org/EXTINFOR MATIONANDCOMMUNICATIONANDTECHNO LOGIES/Resources/2828221141851022286/IC4DOverview.pdf 